\section{Isolation and Purification of a Pemphigus Vulgaris Antigen from Human Epidermis}

\author{
Larry L. Peterson and Kirk D. Wuepper \\ Department of Dermatology, The Oregon Health Sciences \\ University, Portland, Oregon 97201
}

4 bstract. Pemphigus vulgaris is an autoimmune disease associated with an autoantibody directed against a keratinocyte membrane antigen. The purpose of this study was to purify the human pemphigus vulgaris antigen, to produce an antibody to this antigen, and to use the antibody to induce pemphigus in newborn mice. Various techniques to extract the membrane-rich pellet from human epidermal homogenate were compared; $1 \%$ sodium dodecyl sulfate (SDS) and $1 \%$ dimethysulfoxide proved to be superior to extract the pemphigus vulgaris antigen. This antigen was identified by transfer blotting to nitrocellulose paper, incubated with pemphigus vulgaris serum, or 20 control sera, and detected with fluorescein labeled antisera to human IgG.

Since concanavalin A inhibits the binding of pemphigus vulgaris antibody to tissue sections, we studied the binding of the extracted proteins to concanavalin A covalently coupled to Sepharose. Pemphigus vulgaris antigen bound to the concanavalin A column and was released by $0.02 \mathrm{M}$ methyl $\alpha$-D-mannopyranoside. The proteins thus recovered were subjected to AcA 54 gel permeation chromatography, and the pemphigus antigen was detected by the transfer blot assay. The antigen corresponded to a discrete peak at $66,000 \mathrm{D}$ by gel permeation and gave one homogenous band at $33,000 \mathrm{D}$ in ureaSDS-polyacrylamide gel electrophoresis. Monospecific antibody to the antigen raised in rabbits stained human epidermis in the same manner as the pemphigus vulgaris autoantibody and induced pemphigus vulgaris in newborn

This paper was read at the annual meeting of The Society for Investigative Dermatology, Washington, DC, 1983.

Send reprint requests to Dr. Wuepper.

Received for publication 10 June 1983 and in revised form $28 \mathrm{No}$ vember 1983.

J. Clin. Invest.

(c) The American Society for Clinical Investigation, Inc. 0021-9738/84/04/1113/08 $\$ 1.00$

Volume 73, April 1984, 1113-1120 mice when injected intraperitoneally. A pemphigus vulgaris antigen has been purified from adult human epidermis. It is a $66,000-\mathrm{D}$ membrane glycoprotein that is composed of two apparently identical subunits of 33,000 $\mathrm{D}$ each.

\section{Introduction}

Pemphigus vulgaris (PV) ${ }^{1}$ is an autoimmune disease characterized by erosions and blistering of mucous membranes and skin. It has been proposed that an IgG autoantibody binds to a membrane antigen and causes the release of a protease that leads to acantholysis and bulla formation (1).

Since Buetner and Jordan (2) first reported skin autoantibodies in sera of PV patients, investigators have attempted to characterize the skin antigen. Fukuyama et al. (3) demonstrated by immunofluorescent and light microscopy that the pemphigus antigen has a pattern of distribution that corresponds to the keratinocyte glycocalyx. Hashimoto et al. (4) were able to block pemphigus autoantibody binding to human epidermis by first incubating the tissue with concanavalin $A$, a lectin that has been shown to bind to the glycocalyx (5). This was suggestive that the pemphigus antigen was a membrane glycoprotein. Further support for this came recently from Stanley et al. (6) who showed that mouse and human epidermal cell cultures incubated with radiolabeled sugars produced a labeled 130,000-D membrane glycoprotein identified in sodium dodecyl sulfate- (SDS) polyacrylamide gel electrophoresis (PAGE) (SDS-PAGE) after immunoprecipitation with pemphigus sera.

Characterization of the pemphigus antigen from numerous sources has been reported $(7,8,9,10)$. Unfortunately, only indirect methods have been used to identify the antigen such as antibody blocking techniques. In this paper we describe a new immunoblot assay for detecting the antigen. We also report the isolation of human PV antigen and the induction of PV in newborn mice by intraperitoneal injection of monospecific antibodies to the isolated antigen.

1. Abbreviations used in this paper: DMSO, dimethylsulfoxide; PV, pemphigus vulgaris; PMSF, phenylethylsulfonylfluoride; PAGE, polyacrylamide gel electrophoresis; SDS, sodium dodecyl sulfate. 


\section{Methods}

Assays. Fractions to be assayed for PV antigen were first subjected to $1 \%$ SDS, $6 \mathrm{M}$ urea, and 8 or 5\% PAGE (Hoefer Scientific Instruments, San Francisco, CA) by the method of Shapiro et al. (11). Molecular weight markers (Bethesda Research Laboratories, Gathersburg, MD) included insulin $(3,000 \mathrm{~mol} \mathrm{wt})$, bovine trypsin inhibitor $(6,200 \mathrm{~mol}$ $w t)$, cytochrome $C(12,300 \mathrm{~mol} \mathrm{wt})$, lysozyme $(14,300 \mathrm{~mol} \mathrm{wt}), \beta$-lactoglobulin (18,400 D), $\alpha$-chymotrypsin (25,700 mol wt), ovalbumin $(43,000 \mathrm{~mol} \mathrm{wt})$, bovine serum albumin $(67,000 \mathrm{~mol} \mathrm{wt})$, and IgG $(167,000 \mathrm{~mol} \mathrm{wt})$. The proteins in the gel were then electrophoretically blotted to nitrocellulose paper according to Towbin et al. (12) in a BioRad transblot cell (Bio-Rad Laboratories, Richmond, CA). The nitrocellulose paper was then incubated with sera, washed, and incubated with fluorescein-labeled rabbit IgG to human IgG (Calbiochem-Behring Corp., La Jolla, California). Serum used included that from a patient with a clinical, histologic (suprabasilar acantholytic bulla), and an immunofluorescent (ICS 1:160 on direct immunofluorescence using human epidermis) presentation consistent with PV and control sera of a pool from 20 normal patients. The pemphigus sera and the control sera were concentrated fourfold by Amicon ultrafiltration (Amicon Corp., Lexington, MA). Additionally, 10 normal patients' serum were individually concentrated fourfold and tested.

Coomasie Brilliant Blue G-250 (Eastman Kodak Co., Rochester, NY) was used for protein determinations (13). $0.5 \mathrm{mg} / \mathrm{ml}$ concanavalin A was used in all blocking experiments.

Membrane extraction. Human skin was removed from five belowthe-knee amputations $\left(1 \mathrm{~m}^{2}\right)$ and trimmed of excess fat. The skin was then immersed in a $56^{\circ} \mathrm{C}$-water bath for $30 \mathrm{~s}$, which separated the epidermis from the dermis as previously shown (14). The epithelium was subsequently frozen in liquid nitrogen, pulverized, transferred to a polytron (Brinkman Instruments, Inc., Westbury, NY), and homogenized in $100 \mathrm{ml} 0.025 \mathrm{M}$ phosphated-buffered saline (PBS), $\mathrm{pH} \mathrm{7.4,} \mathrm{containing}$
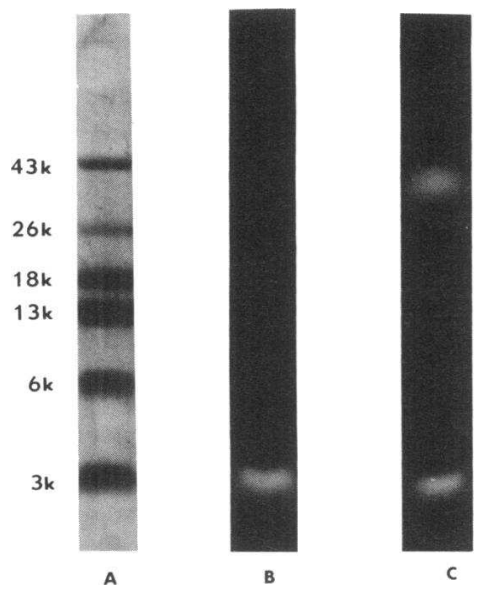

Figure $1.1 \%$ SDS, $8 \mathrm{M}$ urea, $8 \%$ PAGE, and immunoblot of membrane extract. (A) Prestained standards ranging from 43,000 to $3,000 \mathrm{~mol} \mathrm{wt}$. $(B) \mathrm{Hu}-$ man membrane extract has been blotted into nitrocellulose and incubated first with the pooled sera from 20 normal patients followed by a fluorescein-labeled anti-human IgG rabbit IgG. An antigen is present at 3,000 D. Similar results were seen in all 10 individual normal patients' sera. $(C)$ Human mem-

brane extract has been blotted into nitrocellulose and incubated first with the sera from a patient with PV followed by a fluorescein-labeled anti-human IgG rabbit IgG. The autoantibody present in the normal pool is seen, but an autoantibody is also present, directed against a 33,000-D protein, the pemphigus antigen. Four of five other patients with PV showed similar results.

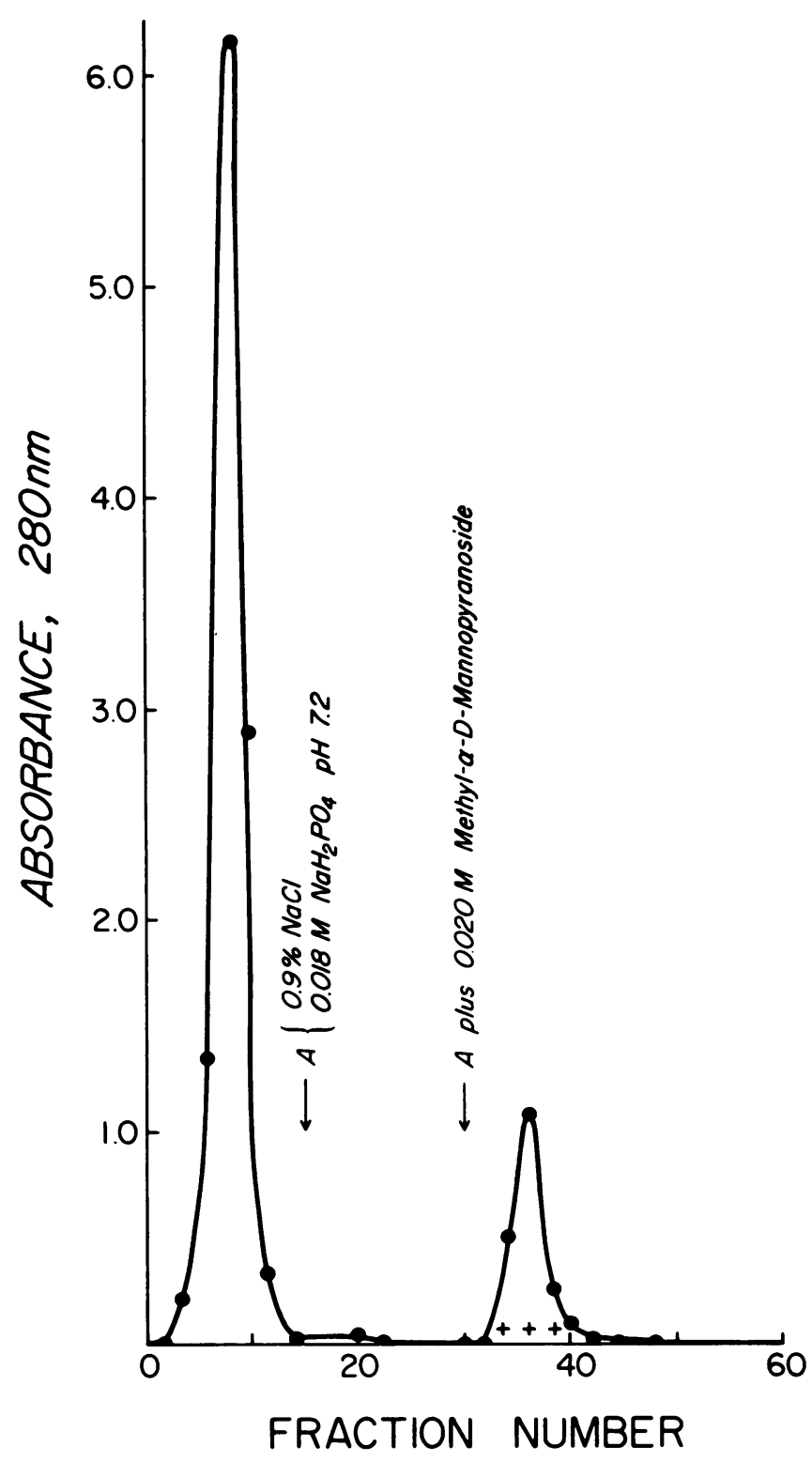

Figure 2. Concanavalin A-Sepharose affinity chromatography. Human membrane extract was applied and the column was washed with a buffer containing $0.9 \% \mathrm{NaCl}$ and $0.018 \mathrm{M} \mathrm{NaH}_{2} \mathrm{PO}_{4}, \mathrm{pH} 7.2$, until the $A_{280}$ was 0 . Bound membrane glycoproteins were then eluted in 2-ml fractions with $0.020 \mathrm{M}$ methyl- $\alpha$-D-manopyranoside in starting buffer. Flow rate was $20 \mathrm{ml} / \mathrm{h}$. Fractions from both peaks were assayed by transblot and activity was present in fractions 34-38(+). These fractions were pooled.

$2 \mathrm{mM}$ phenylmethylsulfonylfluoride (PMSF) and $8 \mathrm{M}$ urea. The homogenate subsequently was centrifuged at $40,000 \mathrm{~g}$ for $45 \mathrm{~min}$. The supernatant was discarded and the membrane-rich pellet was resuspended in $50 \mathrm{ml}$ of $1 \%$ dimethylsulfoxide (DMSO) in PBS containing either $1 \%$ SDS, Triton $X(1,5$, and $20 \%), 10 \mathrm{mM} \mathrm{3-[(3-cholaminopro-}$ 
pyl)dimethylamino]-1-propanesulfonate (Pierce Chemical Co., Rockford, IL), or $5 \mathrm{mM}$ lithium diiodosalicylate (Eastman Kodak Co.). The various suspensions were centrifuged at $40,000 \mathrm{~g}$ for $30 \mathrm{~min}$ and the supernatant was assayed for the pemphigus vulgaris antigen using the immunoblot assay. All procedures were at $4^{\circ} \mathrm{C}$.

Purification of the PV antigen. The extract obtained by using the $1 \%$ DMSO/1\% SDS detergent was used as starting material for purifying the pemphigus antigen. The extract was concentrated to $4 \mathrm{ml}$ by ultrafiltration (Amicon Corp.) and then dialyzed exhaustively for $\mathbf{3} \mathrm{d}$ in a buffer containing $0.9 \% \mathrm{NaCl}$ and $0.018 \mathrm{M} \mathrm{NaH}_{2} \mathrm{PO}_{4}, \mathrm{pH}$ 7.2. Concanavalin A-Sepharose (Pharmacia, Uppsala, Sweden) was equilibrated in the same buffer and poured into a $1-\times 7-\mathrm{cm}$ column. The extract was then applied at $20 \mathrm{ml} / \mathrm{h}$, and the column was washed with buffer until $A_{280}$ was 0 . Bound membrane glycoproteins were then eluted in 2-ml fractions with $0.020 \mathrm{M}$ methyl- $\alpha$-D-mannopyranoside in starting buffer. Fractions containing the pemphigus antigen were pooled, concentrated in $1 \mathrm{ml}$, and dialyzed against PBS. The concentrate was next applied to a 1.5- $\times 90-\mathrm{cm}$ AcA 54 Ultragel column (LKB Western Instruments, Pleasants Hills, California) equilibrated in PBS. Protein markers on the column (Bethesda Research Laboratories, Gathersburg, MD) included blue dextran $(2,000,000 \mathrm{~mol} \mathrm{wt})$, bovine serum albumin $(67,000 \mathrm{~mol}$ $w t)$, carboxypeptidase $(35,000 \mathrm{D})$, egg white trypsin inhibitor $(28,000$ $\mathrm{mol} \mathrm{wt})$, and cytochrome $\mathrm{C}(13,500 \mathrm{~mol} \mathrm{wt})$. Fractions were assayed as above at a flow rate of $6 \mathrm{ml} / \mathrm{h}$. 1-ml fractions were collected. All steps were performed at $4^{\circ} \mathrm{C}$.

Antibody preparation. A New Zealand white rabbit was bled for preimmune sera. Rabbit antisera to the purified pemphigus antigen was prepared by emulsifying $50 \mu \mathrm{g}$ of antigen in $0.5 \mathrm{ml}$ PBS with $0.5 \mathrm{ml}$ Freund's complete adjuvant and by injecting subcutaneously multiple sites on the rabbit's back and inner thighs. Subsequent subcutaneous injections of $30 \mu \mathrm{g}$ of antigen in $0.5 \mathrm{ml}$ PBS emulsified in $0.5 \mathrm{ml}$ of Freund's incomplete adjuvant were made weekly for $3 \mathbf{w k}$. Antibody production was detected by Ouchterlony double immunodiffusion (15).
Induction of $P V$ in mice. The IgG fractions from the above immunized rabbit and a nonimmunized control were isolated by affinity chromatography using staphylococcal protein A coupled to Sepharose 4B (Pharmacia) (16). The IgG fraction was concentrated to $60 \mathrm{mg} / \mathrm{ml}$ by Amicon ultra-filtration (YM-10, Amicon Corp.) and dialyzed against PBS.

Neonatal Balb/c mice (five control and five test), $\sim 12$-h-old, were injected with a 30-gauge needle intraperitoneally with either nonimmunized or immunized IgG on a schedule that included $20 \mathrm{mg} \mathrm{IgG}$ in the a.m. and $20 \mathrm{mg} \mathrm{IgG}$ in the p.m. Mice were biopsied for light microscopy and direct immunofluorescence using fluorescein-labeled goat antibody to rabbit IgG (Calbiochem-Behring Corp.) using a method similar to Stanley et al. (6).

\section{Results}

Assays. The immunoblot of concentrated (pooled or individual) normal patients' serum detected only an autoantibody directed against an $\sim 3,000$-mol wt protein (Fig. 1). The autoantibody was present in all individual normal cases. This autoantibody was also present in the serum from the PV patient, but in addition, an autoantibody against a 33,000-mol wt protein was also detected (Fig. 1). This was presumed to be the PV antigen, and we used its presence as an indicator of a positive assay. Further support for this being the pemphigus antigen was provided by performing the assay with the same patient's serum at the time of clinical remission when direct and indirect immunofluorescence was negative. His serum was concentrated fourfold, but no 33,000-mol wt protein was detected. Additionally, we performed the immunoblot assay on the fourfold concentrated serum of five other patients with PV, and the assay

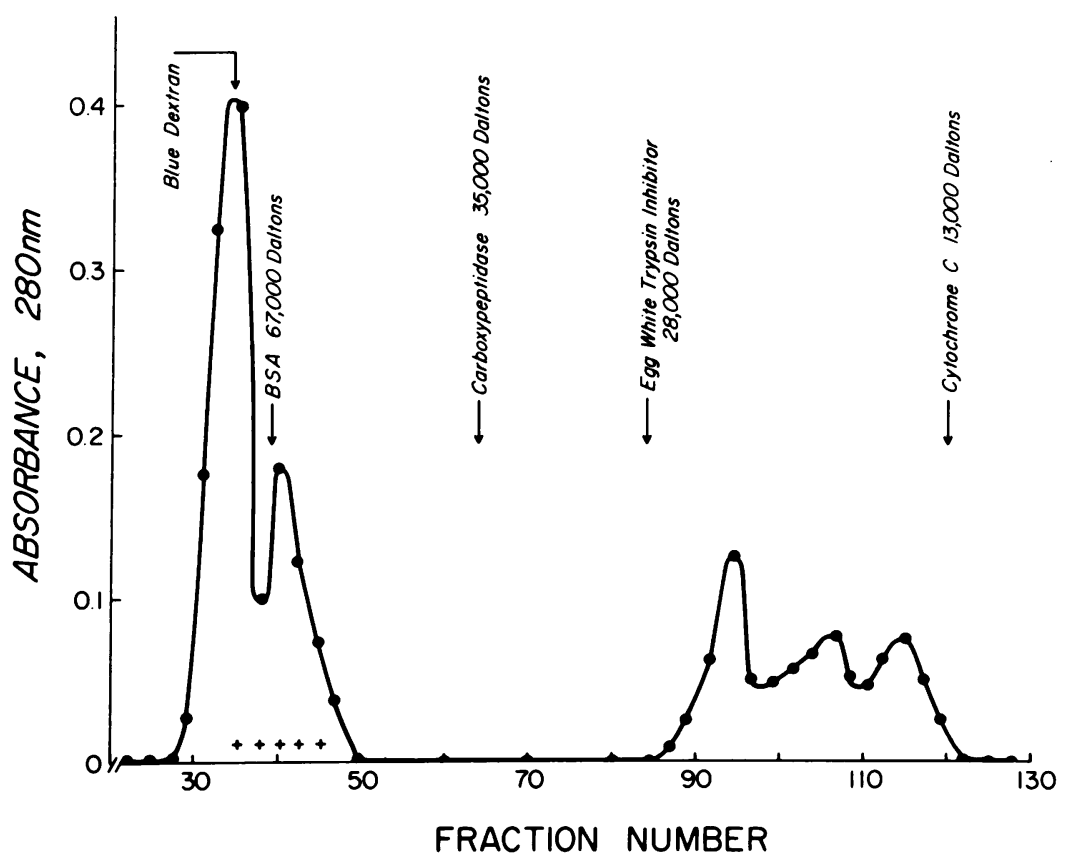

Figure 3. AcA 54 Ultragel column chromatography. The column was preequilibrated with standards ranging from Blue Dextran to cytochrome C. Active glycoprotein fractions from the previous column were applied at a flow rate of $6 \mathrm{~m} / \mathrm{h}$. 1-ml fractions were collected. Activity was present in fractions $36-46(+)$. Fractions 43-46 were pooled. The pemphigus antigen was $66,000 \mathrm{D}$. 


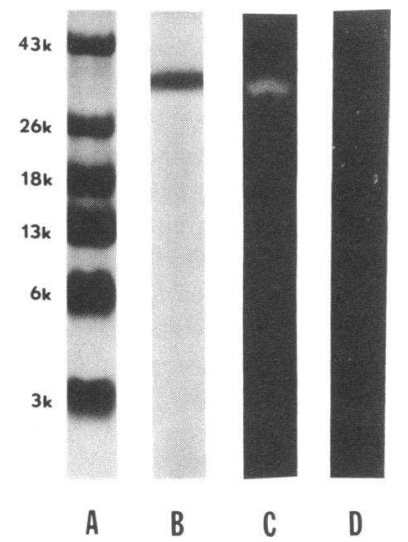

was positive in four out of five with the positive pattern being the same as shown in Fig. 1.

Membrane extraction. Of the numerous detergents tested, only the $1 \%$ DMSO/1\% SDS combination allowed recovery of a detectable antigen by our immunoblot assay. This combination was used for extracting membrane components that provided starting material for pemphigus antigen purification and for preparing an epidermal membrane extract from newborn mouse epidermis.

Purification of PV antigen. Approximately $12 \mathrm{~g}$ wet weight of membrane pellet was obtained after homogenation and centrifugation. The detergent extraction yielded $20 \mathrm{mg}$ of soluble protein. The majority of proteins applied to the concanavalin A-Sepharose affinity column, as shown in Fig. 2, did not bind to the column. Washing with the buffer brought the $A_{280}$ essentially to 0 . The glycoproteins bound were released after applying methyl- $\alpha$-D-mannopyranoside, a sugar that displaced the lower affinity membrane glycoproteins. The immunoblot assay detected pemphigus antigen in fractions eluted only after the sugar was applied to the column. $2 \mathrm{mg}$ of protein was obtained by pooling the fractions that demonstrated activity.

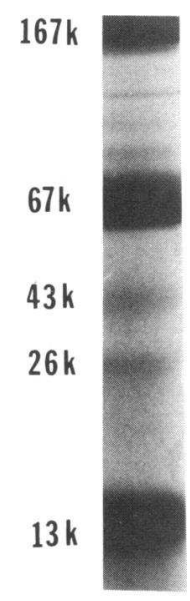

A

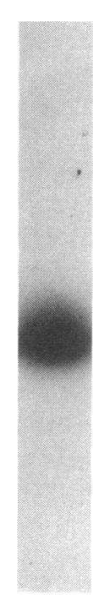

B
Figure 4 B. $1 \%$ SDS, $8 \mathrm{M}$ urea, and $5 \%$ PAGE. $(A)$ Protein standards. $(B)$ Purified human PV antigen.
Table I. Purification of the Pemphigus Antigen

\begin{tabular}{|c|c|c|}
\hline Purification step & Protein recovery & $\begin{array}{l}\text { Protein } \\
\text { recovery yield }\end{array}$ \\
\hline & $m g$ & $\%$ \\
\hline Pellet weight (wet) & 12,000 & \\
\hline \multicolumn{3}{|l|}{ Soluble extract after } \\
\hline SDS/DMSO & 20 & 0.17 \\
\hline \multicolumn{3}{|l|}{ Concanavalin A affinity } \\
\hline chromatography & 2 & 0.017 \\
\hline ACA 54 chromatography & 0.07 & 0.0006 \\
\hline
\end{tabular}

The pemphigus antigen migrated on AcA 54-column chromatography as a single peak at a molecular weight of 66,000 (Fig. 3). Fractions 43-46 were pooled and subjected to $8 \mathrm{M}$ urea-SDS PAGE. Fractions 36-42 did show the presence of PV antigen, but were not used in the pool due to contaminating higher molecular weight proteins. The glycoprotein migrated as a single distinct band at a relative molecular weight $\left(M_{\mathrm{r}}\right)$ of 33,000 and was positive by immunoblot assay (Fig. 4, $A$ and $B$ ). Approximately $70 \mu \mathrm{g}$ of protein was purified. A negative immunoblot was observed if concanavalin $A$ was incubated on the nitrocellulose before the pemphigus antibody was added. Protein yield at each step is presented in Table I.

Rabbit antibody to $P V$. Monospecific antibody to purified PV antigen was detected $1 \mathrm{wk}$ after the third injection and is shown in Fig. $5 \mathrm{~A}$. Preimmunization serum did not cross react with the antigen. A single line of identity is seen between the human and mouse preparations and the rabbit antibody. In Fig. $5 \mathrm{~B}$, a single line of identity is seen between the concentrated

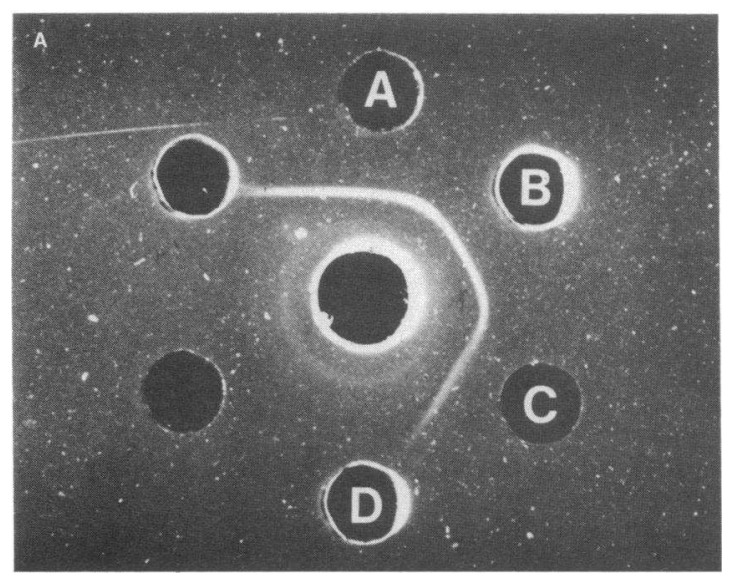

Figure $5 \mathrm{~A}$. Ouchterlony double immunodiffusion. Center well contains monospecific rabbit antisera to the human pemphigus antigen. Well $A$ contains concentrated human membrane extract, well $B$ contains purified pemphigus antigen, well $C$ contains concentrated mouse membrane extract, and well $D$ contains buffer. A single line of identity is seen. If well $A$ is substituted with preimmunized serum, no lines are apparent. 


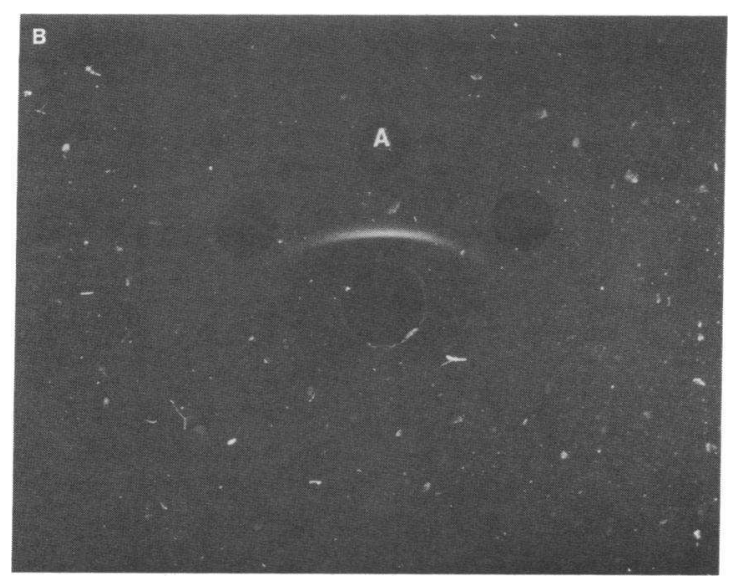

Figure 5 B. Center well contains concentrated PV serum. Well $A$ contains the purified pemphigus antigen. A single line of identity is seen.

human PV serum and the human pemphigus antigen. Indirect immunofluorescent staining of human epidermis showed an intercellular staining pattern similar to that seen with the PV autoantibody from human serum (Fig. 6), and concanavalin A blocked this staining.

Induction of $P V$ in mice. Approximately $36 \mathrm{~h}$ after the initial injection, 4/5 mice injected with the PV-specific rabbit IgG formed blisters over their bodies (Fig. 7). No blisters were seen in the controls. Light microscopy revealed a suprabasilar split (Fig. 8). Direct immunofluorescence showed a similar intercellular staining pattern as seen in Fig. 6. Control mice were negative.

\section{Discussion}

From our immunoassay, it was apparent that, even in normal patients, circulating autoantibodies may be present. These may represent antibodies that are directed against stratum corneum, membrane (blood group, $\mathrm{MN}$, etc.), or cytoplasmic antigens (17). Grab and Inderbitzen (18) have shown by blocking experiments that the pemphigus antigen is not related to blood group substances $\mathrm{A}$ and $\mathrm{B}$. This new assay method enabled us to determine the presence and $M_{\mathrm{r}}$ of the pemphigus antigen. It should allow us to survey and identify different pemphigus an-

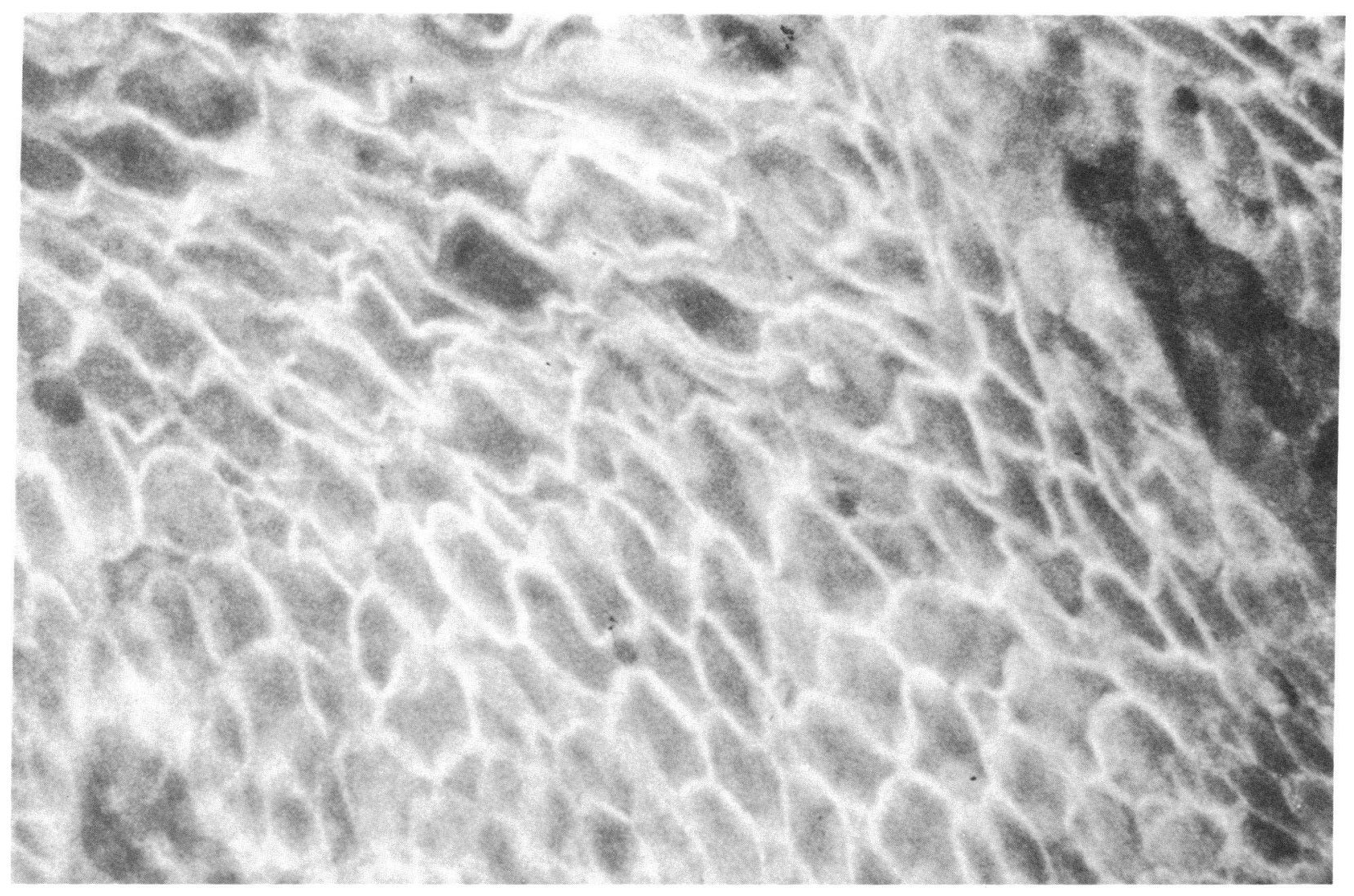

Figure 6. Frozen section of human epidermis incubated first with monospecific rabbit antisera to the human pemphigus antigen and then incubated with fluorescein-labeled goat anti-IgG to rabbit IgG.
An intercellular staining pattern is present throughout the epidermis $(\times 100)$. 


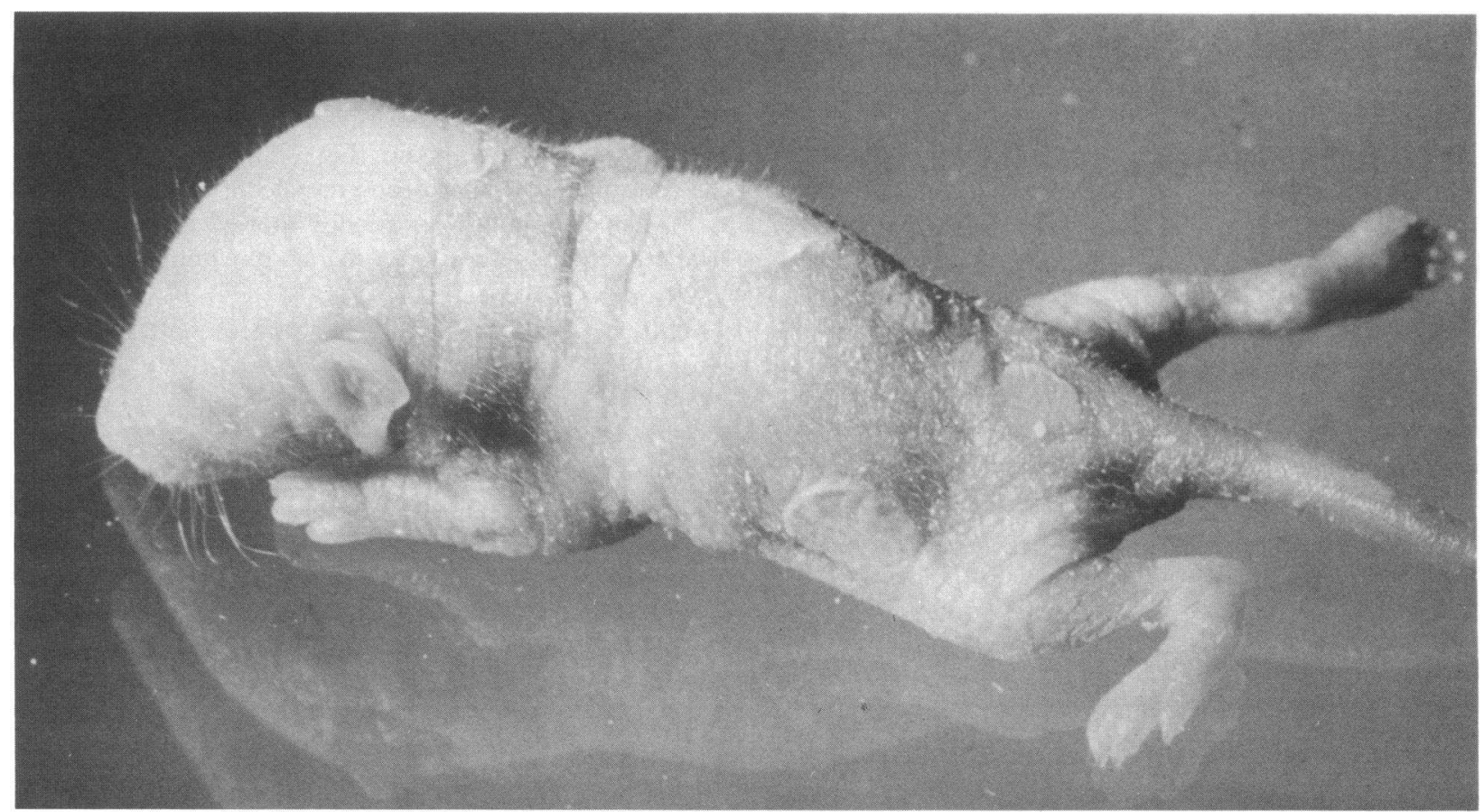

Figure 7. Neonatal mouse injected $36 \mathrm{~h}$ earlier with a total of $40 \mathrm{mg}$ of monospecific rabbit $\mathrm{IgG}$ to the human pemphigus antigen. Blisters are present.

tigens from different patients and from variant forms of pemphigus like vegetans, foliaceous, and erythematosus.

From testing five other patients with PV, it is evident that there is probably more than one antigen involved, and antigens may vary from individual to individual. Our antigen's molecular weight is approximately half the size of Stanley et al. (6). This could be explained by: $(a)$ difference in extraction procedure, (b) antibodies directed toward different membrane antigens, and/or $(c)$ differences in glycoproteins due to Stanley's work in cell culture. Our work on envelope precursors shows great differences in molecular weights and other physical properties between cell culture proteins and actual epidermal proteins (19).

An important aspect of membrane protein purification is choice of a suitable detergent. While Triton $X$, a nonionic detergent, prevents enzyme denaturation, it has been shown to be inferior to (10 mM 3-[(3-cholaminopropyl)dimethylamino]1-propanesulfonate and lithium deoxycholate in breaking protein-protein interactions $(20,21)$. We found that SDS was needed to solubilize antigen in quantities large enough to be detected by our assay system. SDS, a 288.4-D amphipathic molecule, is still the most widely used membrane detergent (22) and appeared not to destroy antigenic determinants during purification. By exhaustive dialysis (22), enough SDS was removed to allow the two subunits to reaggregate before the affinity column step.

Concanavalin A-Sepharose affinity chromatography proved to be an excellent method to isolate glycoproteins from other membrane fractions. Lloyd (23) has shown that concanavalin
A has a high degree of affinity for $\alpha$-D-mannopyranosyl residues. This information led us to use $\alpha$-D-mannopyranoside to elute the membrane glycoproteins off the column. Our antigen migrated at a $M_{\mathrm{r}}$ of 66,000 on gel filtration and at 33,000 on ureaSDS-PAGE. We used the trailing edge to pool to avoid contamination from the void volume. The exact molecular weight is uncertain, since glycoproteins are known to migrate anomalously (24). Regardless, its weight correlates best with the human esophageal antigen reported to be 66,000 by sucrose density gradient ultracentrifugation (25).

Direct evidence that this antigen and the rabbit antibody directed against it were important for blister formation was provided by our mouse model. The experimental design was similar to Anhalt et al. (26). They intraperitoneally injected concentrated, PV sera and successfully induced pemphigus in neonatal mice. Earlier attempts had failed in monkey (27) and athymic nude mice (28). These failures were presumably due to the inability to obtain high enough circulating autoantibody levels in the laboratory animals. Additionally, the neonatal mouse is an ideal model, since a mature immune system is lacking, this allows the injection of foreign material without rejection. In our study, data shown in Fig. $5 \mathrm{~A}$ suggests that the rabbit antibody was directed against the same cell surface antigen in mouse and human epidermis, since no spurs were present on the Ouchterlony plates.

This paper presents definitive evidence that rabbit antibodies to a human pemphigus antigen induce a suprabasilar split and 


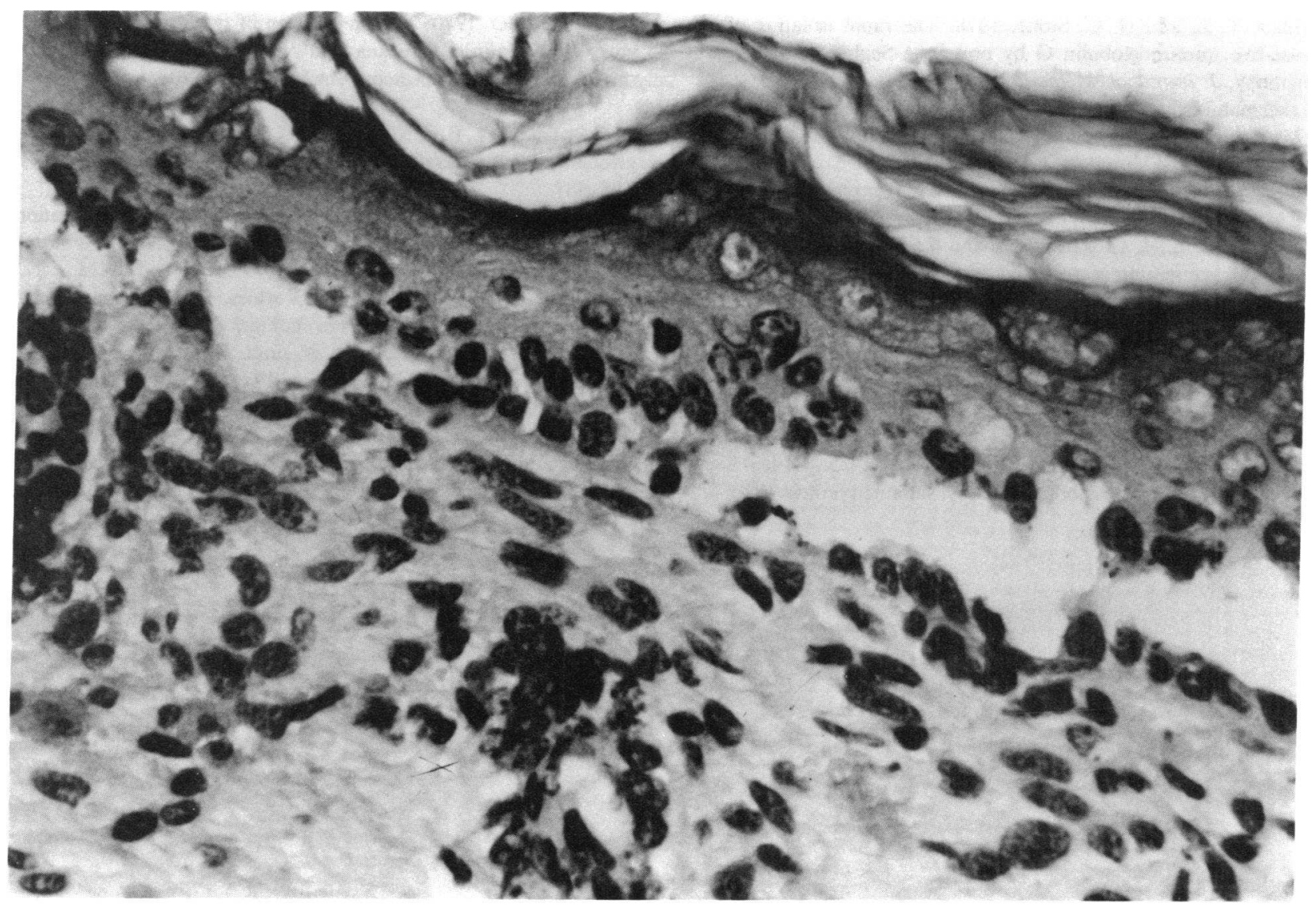

Figure 8. Biopsy of an induced blister showing a suprabasilar split. (Hematoxylin and eosin $\times 160$ ).

blister formation in mice. The events occurring after antibody binding that lead to acantholysis remain unknown.

\section{References}

1. Farb, R. M., R. Dykes, and G. S. Lazarus. 1978. Anti-epidermalcell-surface pemphigus antibody detaches viable epidermal cells from culture plates by activation of proteinase. Proc. Nat'l. Acad. Sci. USA. 75:459-463.

2. Buetner, E. H., and R. E. Jordan. 1964. Demonstration of skin auto-antibodies in sera of pemphigus vulgaris patients by indirect immunofluorescent staining. Proc. Soc. Exp. Biol. Med. 117:505-510.

3. Fukuyama, K., S. D. Douglas, D. L. Tuffaneli, and W. L. Epstein. 1970. Immunohistochemical method for localization of antibodies in cutaneous disease. Am. J. Clin. Pathol. 54:410-416.

4. Hashimoto, K., L. E. King, Y. Yamanishi, E. H. Beachey, and E. Maeyen. 1974. Identification of the substance binding pemphigus antibody and Concanavalin A in the skin. J. Invest. Dermatol. 52:423435.

5. Brysk, M. M., and J. M. Snider. 1982. Concanavalin A binding glycoproteins of epidermal cells. J. Invest. Dermatol. 79:193-197.

6. Stanley, J. R., M. Yaar, P. Hawley-Nelson, and S. I. Katz. 1982. Pemphigus antibodies identify a cell surface glycoprotein synthesized by human and mouse keratinocytes. J. Clin. Invest. 70:281-288.

7. Grab, P. J., and T. M. Inderbitzin. 1967. Experimental production in rabbits of antiepithelial autoantibodies. J. Invest. Dermatol. 49:637641.

8. Ablin, R. J., and E. H. Beutner. 1968. Absorption studies on antigen(s) of the esophageal mucosa reactive with autoantibodies of pemphigus. Int. Arch. Allergy. 33:227-238.

9. Miyagawa, S., T. Hojo, H. Ishii, J. Yoshioka, and K. Sakamoto. 1977. Isolation and characterization of soluble epidermal antigens reactive with pemphigus antibodies. Acta Dermato. Venereol. 57:7-13.

10. Diaz, L. A., H. Patel, and N. J. Calvanico. 1980. Isolation of pemphigus antigen from human saliva. J. Immunol. 124:760-765.

11. Shapiro, A. L., E. Vinuela, and J. V. Maizel. 1967. Molecular weight estimation of polypeptide chains by electrophoresis in SDS-polyacrylamide gels. Biochem. Biophys. Res. Comm. 28:815-820.

12. Towbin, H., T. Staehelin, and J. Gorden. 1977. Electrophoretic transfer of proteins from polyacrylamide gels to nitrocellulose sheets: procedure and some applications. Proc. Nat'l. Acad. Sci. USA. 76:43504354.

13. Buxman, M. M., and K. D. Wuepper. 1978. Cellular localization of epidermal transglutaminase: a histochemical and immunochemical study. J. Histochem. Cytochem. 26:340-348.

14. Peterson, L. L., and M. M. Buxman. 1981. Rat hair follicle and epidermal transglutaminases: biochemical and immunochemical isoenzymes. Biochim. Biophys. Acta. 657:268-276.

15. Ouchterlony, O. 1968. Handbook of immunodiffusion and immunoelectrophoresis. Ann Arbor Science, Ann Arbor, MI. 
16. Miller, T. J., and H. O. Stone. 1978. The rapid isolation of ribonuclease-free immunoglobulin $\mathrm{G}$ by protein A-Sepharose affinity chromatography. J. Immunol. Methods. 24:111-125.

17. Ackermann-Schopf, C., R. Ackerman, P. I. Terarasaki, and J. Levy. 1974. Natural and acquired epidermal autoantibodies in man. $J$. Immunol. 112:2063-2067.

18. Grob, P. J., and T. M. Inderbitzen. 1967. Pemphigus antigen and blood group substances A and B. J. Invest. Dermatol. 49:285-289.

19. Peterson, L. L., J. G. Zettergren, and K. D. Wuepper. 1983. Biochemistry of transglutaminasees and cross-linking in the skin. $J$. Invest. Dermatol. 81(1):95s-100s.

20. Hjelmeland, L. M. 1980. A nondenaturing zwitterionic detergent for membrane biochemistry: design and synthesis. Proc. Nat'l. Acad. Sci. USA. 77:6368-6370.

21. Simonds, W. F., G. Koski, R. A. Streaty, L. M. Hjelmeland, and A. K. Werner. 1980. Solubilization of active opiate receptors. Proc Nat'l. Acad. Sci. USA. 77:4623-4627.

22. Waehneldt, T. V. 1975. Sodium dodecyl sulfate in protein chemistry. BioSystems. 6:176-187.
23. Lloyd, K. O. 1970. The preparation of two insoluble forms of the phytohemagglutinin, Concanavalin A, and their interactions with polysaccharides and glycoproteins. Arch. Biochem. Biophys. 137:460468.

24. Kobylka, D. A., B. C. Khettry, and K. L. Carraway. 1972. Proteins and glycoproteins of the erythrocyte membrane. Arch. Biochem. Biophys. 148:475-487.

25. Shu, S. Y., and E. H. Beutner. 1973. Isolation and characterization of antigens reactive with pemphigus antibodies. J. Invest. Dermatol. 61:270-276.

26. Anhalt, G. J., R. S. Labib, J. J. Vorhies, T. F. Beals, and L. A. Diaz. 1982. Induction of pemphigus in neonatal mice by passive transfer of IgG from patients with the disease. N. Engl. J. Med. 306:1189-1196.

27. Sams, W. M. Jr., and R. E. Jordan. 1971. Pemphigus antibodies: their role in disease. J. Invest. Dermatol. 56:474-479.

28. Buschard, K., E. Dabelsteen, and P. Bretlau. 1981. A model for the study of autoimmune diseases applied to pemphigus: transplants of human oral mucosa to athymic nude mice binds pemphigus antibodies in vivo. J. Invest. Dermatol. 76:171-173. 